\title{
Sponges (Porifera) as bioindicator species of environmental stress from de Gulf of Annaba (Algeria)
}

\author{
Khati Wyllia ${ }^{\text {** }}$ Bensafia Nabila', Ouali Kheiredine ${ }^{2} \&$ Derbal Farid ${ }^{3}$ \\ ${ }^{1}$ Biodiversity and Pollution of Ecosystems Laboratory, Chadli Bendjedid University, El-Tarf, B.P. 73, 36000 Algeria \\ ${ }^{2}$ Laboratory of Environmental Biosurveillance, Badji Mokhtar University, BP 12, Annaba 23000, Algeria \\ Laboratoire Bioressources, Université Badji Mokhtar Annaba, Algeria \\ ${ }^{*}$ Corresponding author, e-mail: khati-hm@hotmail.com
}

ABSTRACT

\begin{abstract}
The aim of the study was to determine seasonal variations of two biomarkers of oxidative stress, Glutathione (GSH) and Glutathione S-transferases (GSTs), in sponge Sarcotragus spinosulus Schmidt, 1862 (Porifera Irciniidae). The samples were collected during the four seasons in 20162017 at two sites in the Gulf of Annaba (northeast of Algeria): Cape de Garde, which is some distance from any source of pollution, is considered a relatively clean site, while Alzon is a site exposed to various sources of industrial, urban and harbour pollution. The results show a significant seasonal decrease in GSH rate in Alzon compared with those at Cape de Garde. Moreover, GST activity increased significantly in Alzon relative to Cape de Garde site, with a maximum activity showed in autumn. This difference between those two sites was observed for all seasons, with more effect in spring and winter. The results obtained showed that under stressful conditions due to anthropogenic factors, some physiological processes of sponges can be affected. Thus, $S$. spinosulus appears to be a suitable sentinel species for the assessment of ecotoxicological risk in the Gulf of Annaba. Sponges present most of the characteristics researched in bioindicators of pollution and consequently have been proposed to constitute a "Sponge Watch Program".
\end{abstract}

KEY WORDS Sponges; Marine Pollution; Biomarkers; Mediterranean; Bioindicator.

Received 06.09.2018; accepted 27.10.2018; printed 30.12.2018; published online 07.01.2019

\section{INTRODUCTION}

Highly productive areas such as estuaries and coastal areas are among the most widely modified and threatened ecosystems, mainly due to urban development, industrialization and tourism (Clark, 2011; Walker et al., 2012). As a result, complex mixtures of contaminants are continually released into these ecosystems, reducing water quality and placing severe restrictions on organisms. This can ultimately lead to a decline in natural resources $(\mathrm{Ca}-$ jaraville et al., 2000; Monserrat et al., 2007; Cravo et al., 2009). Among these areas, the Gulf of Annaba is constantly threatened because of its proxi- mity to port activities, urban and industrial discharges and active agricultural areas of eastern Algeria.

In recent years, a number of biomarkers have been introduced into environmental biomonitoring programs for the assessment of stress caused by pollution, particularly in aquatic organisms (Müller et al., 2000). These biomarkers include (i) exposure biomarkers, which are (only) indicative of exposure to environmental stress, and (ii) effect biomarkers, which are indicative of both exposure and occurrence of adverse effects (Sanders, 1990). The goal of biomarker-based programs is to set up early warning systems to detect environmental stresses before irreversible damage occurs. 
Contaminants usually appear in the environment as complex mixtures that can cause interactive effects on biota that can not be evaluated by chemical analysis alone. For this purpose, biomarkers offer an integrated assessment of exposure levels and effects of pollutants on wildlife. Several biomarkers are more specific for certain types of xenobiotics, and therefore the use of a biomarker battery associated with chemical analyses has been strongly recommended for inclusion in monitoring programs (OSPAR Commission, 2000; ICES, 2008). Two biomarkers were selected in this study; Glutathione (GSH), tripeptide, capable of directly inactivating radical species by neutralizing them, abd Glutathione $\mathrm{S}$ transferase (GST), a phase II enzyme involved in the detoxification of organic xenobiotics (Habig et al., 1974; Lee et al., 1988).

It is only in the last 20 years that sponges have been used as bioindicators for environmental risk assessment, as respond in a very sensitive manner (Müller et al., 2000), and are able to filter every day a volume of water corresponding to several times their own body volume (Vogel, 1977). Given their way of life, these organisms are natural candidates for participation in the development of quality grids. Several studies have already shown the potential of some representatives of this phylum to accumulate various xenobiotics or to express biological responses to anthropogenic disturbance. Unlike that of the upper metazoa, the tissue differentiation of sponges is poorly developed. These organisms do not have organs or real tissues.

As a result, the accumulation of xenobiotics and

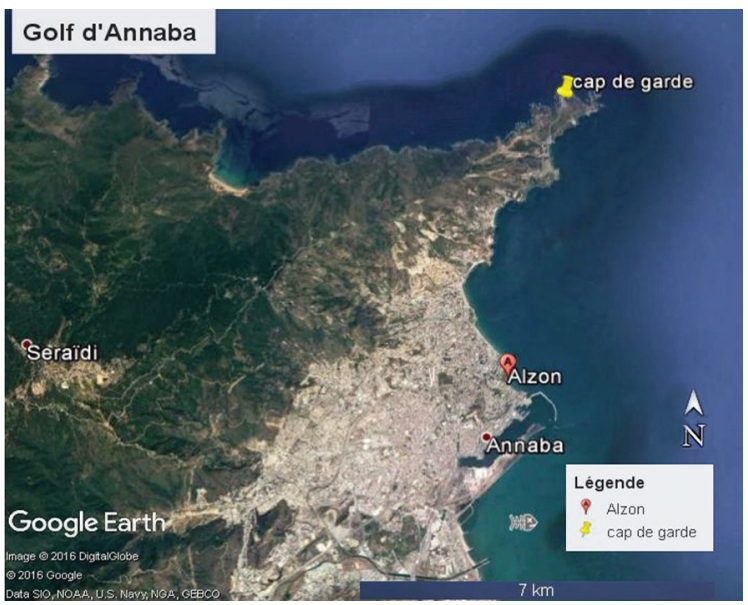

Figure 1. The study area: Gulf of Annaba (Algeria). the biological responses that their toxicity generates must be measurable in the same way throughout the body of the animal. Finally, their very simple organization and their ability to regenerate after cuttings make them particularly suitable organisms for aquarium or experiments in situ (Abed, 2011). Much work has concerned the responses of these organisms to metal accumulation in in their midst, but very few have studied the variations of biomarkers as biological tools in assessing the quality of the environment.

In this context of biomonitoring the water quality of the Gulf of Annaba, we were interested in the antioxidant system involving glutathione and the enzymes associated with its metabolism in the tissues of Sarcotragus spinosulus Schmidt, 1862 (Porifera Irciniidae) at two sites for their potential as biomarkers of exposure in aquatic ecotoxicology as demonstrated by many studies on other organisms.

\section{MATERIAL AND METHODS}

The study was conducted in the Gulf of Annaba, a coastal area between Cape Rosa $\left(8^{\circ} 13^{\prime \prime} \mathrm{E}-36^{\circ} 57^{\prime \prime}\right.$ $\mathrm{N})$ to the east and Cape de Garde to the west $\left(7^{\circ} 47^{\prime \prime} \mathrm{E}\right.$ $\left.-36^{\circ} 58^{\prime \prime} \mathrm{N}\right)$. This sector is considered having a economic vocation (industrial activities, fishing and tourism).

The sampling area was delimited according to the following parameters: accessibility to the site, availability of biological material (sponges) and proximity to sources of pollution (domestic and industrial). For this, we have chosen two stations, one located in periurban area, on the west side of the port of Annaba (station I: Alzon, geographical position: $\left.36^{\circ} 54^{\prime} 57.54^{\prime \prime} \mathrm{N}-07^{\circ} 46^{\prime} 13.29^{\prime \prime} \mathrm{E}\right)$ and the other far from domestic and industrial pollution (station II: Cape de Garde, geographical position: $36^{\circ} 58^{\prime} 3.25^{\prime}$ N - 0747’28.3”E) (Fig. 1).

Samples of $S$. spinosulus, approximately $3 \mathrm{~cm}$ thick tissue and 10 individuals per station, were collected in free diving between 0 and $3 \mathrm{~m}$ during four seasons (2016/2017): autumn (October), winter (January), spring (April) and summer (August). The samples were transported in seawater immediately to the laboratory. All the manipulations concerning the assay of the different biomarkers studied during the grinding of the tissues of the sponge were carried out at $4{ }^{\circ} \mathrm{C}$, in ice. 
After milling one gram of sponge tissue, using an ultrasonic grinder, and homogenizing the tissues in the phosphate buffer $(\mathrm{pH}=7.4,0.1 \mathrm{M})$, the cell suspension was centrifuged At $14,000 \mathrm{rpm}$ at $4{ }^{\circ} \mathrm{C}$ for $30 \mathrm{~min}$, the obtained supernatant was aliquoted into eppendorf tubes and stored immediately at $-24^{\circ} \mathrm{C}$ for further analysis of the oxidative stress parameters.

The estimation of reduced glutathione (GSH) concentrations was carried out according to the method of Weckbecker \& Cory (1988), the results obtained were expressed in $\mu \mathrm{mol} / \mathrm{mg}$ of protein. The protein content was determined according to the colorimetric method of Bradford (1976). The activity of glutathione-S-transferase (GST) was measured according to the method of Habig et al. (1974). The values obtained were expressed in $\mu \mathrm{mol} / \mathrm{min} / \mathrm{mg}$ of proteins.

The results were expressed as mean \pm standard error (SD). The comparison of the average values between the stations and between seasons was carried out by Student's t-test. Seasonal effects and sampling sites were tested by a two-way analysis of variance (ANOVA). All statistical analyses were performed using the Minitab 16 software (version 16.1.1).

\section{RESULTS}

The concentration of glutathione in S. spinosulus tissues ranged from 0.168 to $0.683 \mu \mathrm{mol}$ $\mathrm{GSH} / \mathrm{mg}$ protein for Cape de Garde sponges with a peak recorded in winter and between 0.229 and $0.483 \mu \mathrm{mol} \mathrm{GSH} / \mathrm{mg}$ protein for Alzon with a peak in summer (Fig. 2). The statistical comparison between seasons shows that at the Cap de Garde the concentrations of GSH do not differ between spring and summer, while in Alzon it is similar in winter and summer. Significant differences were observed between the two stations and for the same season throughout the year (Table 1).

Figure 3 expresses GST activities, recorded in Sarcotragus spinosulus tissues where it was found that the maximum values recorded for the two stations are in autumn $(0.283 \mu \mathrm{mol} \mathrm{GST} / \mathrm{min} / \mathrm{mg}$ protein for Cape de Garde and $0.325 \mu \mathrm{mol} \mathrm{GST} / \mathrm{min} / \mathrm{mg}$ protein for Alzon), while the minimum is observed in winter $(0.124 \mu \mathrm{mol} \mathrm{GST} / \mathrm{min} / \mathrm{mg}$ protein for Cape de Garde and $0.162 \mu \mathrm{mol} \mathrm{GST} / \mathrm{min} / \mathrm{mg}$ protein for Alzon). ANOVA shows that there are no significant differences in GST activities between spring and

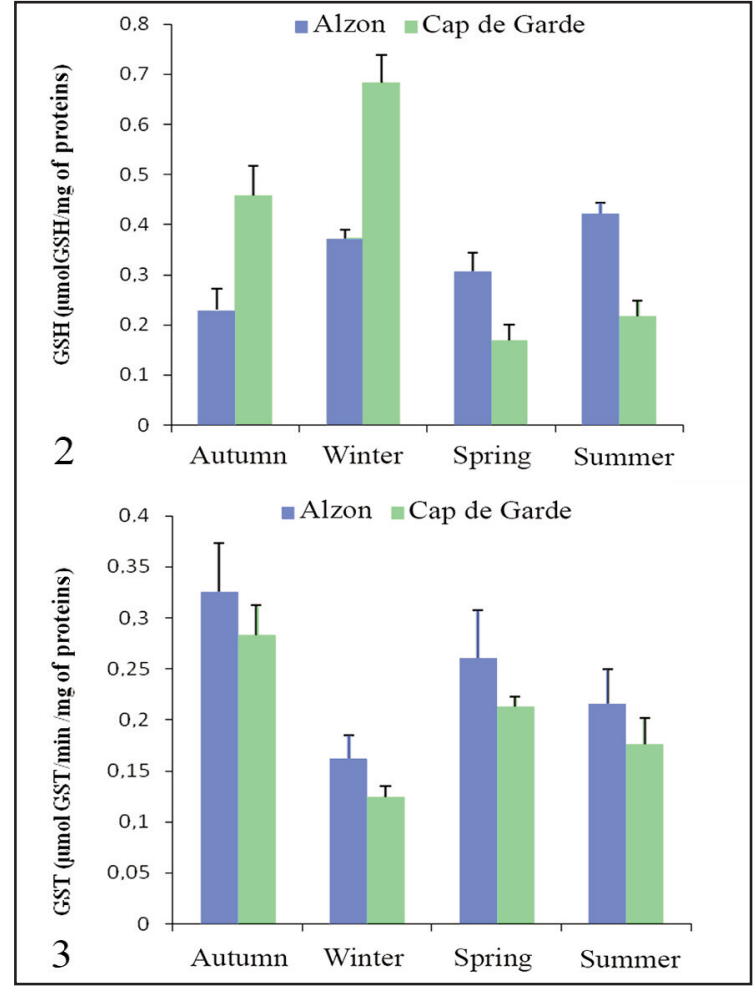

Figure 2. Variation of GSH levels in the tissues of Sarcotragus spinosulus of the Gulf of Annaba (Algeria).

Figure 3. Variation of GST activities in Sarcotragus spinosulus tissues in the Gulf of Annaba (Algeria).

\begin{tabular}{|c|c|c|c|}
\hline Source of variation & Fobs & $\mathbf{P}$ & Signification \\
\hline Stations & 21.16 & 0.000 & $* * *$ \\
\hline Seasons & 56.20 & 0.000 & *** \\
\hline Stations - seasons & 0.05 & 0.984 & n.s \\
\hline \multicolumn{4}{|c|}{$\begin{array}{l}\text { *** highly significant difference at } \mathrm{P}<0.001 ; \mathrm{n} . \mathrm{s} \text { : not significant } \\
1\end{array}$} \\
\hline Source of variation & Fobs & $\mathbf{P}$ & Signification \\
\hline Stations & 18.21 & 0.000 & $* * *$ \\
\hline Seasons & 112.88 & 0.000 & $* * *$ \\
\hline Stations - seasons & 126.36 & 0.000 & $* * *$ \\
\hline
\end{tabular}

Table 1. Analysis of variance with two classification criteria (ANOVA) of GSH activities analyzed in Sarcotragus spinosulus from Gulf of Annaba, Algeria (stations-seasons).

Table 2. Analysis of variance with two classification criteria (ANOVA) of GST activities in Sarcotragus spinosulus from Gulf of Annaba, Algeria (stations-seasons). 
summer for the two sites studied. The student's ' $t$ ' test shows a very significant difference for the same season (fall and spring) and between the two sampling stations (Table 2).

Seasonal variation of GST activity $(\mu \mathrm{M} / \mathrm{min} / \mathrm{mg}$ protein) in the tissue of Sarcotragus spinosulus was sampled in two sites of the Gulf of Annaba, Alzon and Cape de Garde (mean $\pm \mathrm{SD}, \mathrm{n}=10$ ).

\section{DISCUSSION}

A biomarker is a biological parameter and early tool for the effect of a contaminant on an organism (Mistretta \& Charlier, 2013). In some cases, pollutant-induced alterations to these biological parameters can lead to behavioral and biochemical changes (Kaiser, 2001). In all the results, the effect of the seasons and the site of sampling is significantly highlighted with respect to the biomarkers of the oxidative stress of phase 1 and 2 of the detoxification system, determined at the tissue level of the sponge S. spinosulus. Many studies describe seasonal-related activity modifications for other antioxidant enzymes in marine bivalves Mytilus galloprovincialis Lamark, 1819 (Amiard et al., 2008) and freshwater bivalve Corbicula fluminea O.F. Müller, 1774 (Vidal, 2001). On the other hand, Livingstone (2010) observed that $M$. edulis Linnaeus, 1758 phase I detoxification enzymes are induced by seasonal parameters independent of the presence of contaminants in their living environment.

A highly significant $(\mathrm{P}<0.001)$ reduction in glutathione rate was observed in winter and autumn at the Alzon site compared to the Cape de Garde. Indeed, it is subject not only to urban discharges without prior treatment, but also to landfills influenced by natural factors such as currents and wadis (Khammar, 2008). During these cold seasons, floods and showers cause an increase in the flow and consequently that of the turbulence of the medium following a resuspension of the fine materials, which can be at the origin of a metallic contamination. Most of these pollutants tend to accumulate in the food chain and especially at the level of sedentary organisms such as sponges. These sessile animals are very powerful active filterers, whose aquifer system gives them the ability to filter a volume of water equal to their own volume. Several studies have already shown the potential of some representatives of this phylum to accumulate various xenobiotics or to express biological responses to anthropogenic disturbance (Nakhlé, 2003). The work of Belabed (2010), Belabed \& Soltani (2013) and Boutabia (2016), reported metal pollution in the Gulf of Annaba, both in water and in sediment. These results confirm the work done by Amira et al. (2011) who reported a decrease in GSH levels in Donax trunculus Linnaeus, 1758 collected at Sidi Salem, a site not far from Alzon. Several studies confirm the results obtained and help to better explain the relationship between the decrease in GSH levels and the level of environmental contamination (Verlecar et al., 2008).

In contrast to variations in GSH levels, GST activities show significant increases during all seasons at the anthropised site (Alzon), with a maximum noted in autumn. GST plays an important role in the detoxification of organisms (Cossu et al., 1997), it can be induced by certain pollutants (Roméo et al., 2003; Regoli et al., 2004). There are systems developed by living beings to metabolize xenobiotics that play a key role in the adaptation of living organisms to their chemical environment (Mansuy, 2013).

Our results seem consistent with the work of Deviller et al. (2005), who show in a biomonitoring study differences in GST activity with the season, with maximal activities in March-April, and the weakest in July-August. Alterations in the rate and/or activity of biotransformation enzymes are the most sensitive biomarkers of effect (Van der Oost et al., 2003). These enzymes can be inhibited or activated by exposure to a xenobiotic that is highly reliable in molluscs (Cajaraville et al., 2000). In comparison with the reference site, the seasonal increase in GST, obtained during our study, results in a strong activity of detoxification of sponges that would be related to their level of exposure to pollution, as well as probably tidal dynamics that could have a major influence on the quality and management of the pollutant load that transits through estuaries before being discharged into the sea. Similar results were obtained at Sidi Salem, with Donax trunculus (Abbes, 2003), where a seasonal increase in GST was also reported depending on the season. Or, the work of Funes et al. (2006), which shows an increase in GST activity following a metal pollution gradient depending on the season. Other factors may also be behind the induction of GST activities, such as temperature, $\mathrm{pH}$, oxygen, as it may be related to the reproductive cycle of the animal (Chouahda, 
2006). Stimulation of GST activity was also found by Canesi et al. (2007) in Mytilus sp. exposed to wastewater. The same results on $D$. trunculus in the Gulf of Annaba have also been reported by several other authors (Amira et al., 2011; Soltani et al., 2012). Thus, the increase in GST values would be due to oxidative stress where the activity of GST increases by catalyzing conjugation reactions between a peptide, glutathione and reactive molecules that resulted in detoxification of the body to allow their elimination (Chatterjee \& Bhattacharya, 1984).

\section{CONCLUSIONS}

In this preliminary study, sponge $S$. spinosulus in particular and sponges in general appear to be excellent bioindicator models that are very sensitive to environmental variations and that could be effective in the biomonitoring programs of environmental disturbance, associated with the exploitation of biomarkers of oxidative stress that can account for a wide spectrum of pollutants, whose previous work on sponges concerned only metallothioneines (metal stress proteins).

\section{ACKNOWLEDGEMENTS}

We thank the laboratory "biosurveillance environnemental" which has made available to us all the material for the practice of biomarkers.

\section{REFERENCES}

Abbes A., 2003. Variation spatio-temporelle de l'activité de trois biomarqueurs du stress environnemental (AchE, GST et LDH) chez Ruditapes decussatus et Carduim glaucum (Mollusca, Bivalvia) provenant de la lagune El Mellah. Mémoire de Magister, Université de Annaba: 26-107.

Abed C., 2011. Spongiaires Ircinidae de Méditerranée: chimiotaxonomie, métabolites volatils et bio-indicateurs de pollution par les éléments traces métalliques. Thèse de Doctorat en Océanographie. Université de la Méditerranée Aix-Marseille II. Ecole Doctorale Science de l'environnement, $301 \mathrm{pp}$.

Amiard J.C., Amiard-Triquet C., Aitzar F.A., Berth B., Cossu-Leguille C., Dedourge O., Denis F., Durou C., Geffard A., Giamberini L., Huet M., Laroche J., Lemiere S., Marchand J., Minier C., Mouneyrac C.,
Pellerin J., Pery A., Rodius F., Romeo M. \& Vasseur P., 2008. Les biomarqueurs dans l'évaluation de l'état écologique des milieux aquatiques. Ed. Tec \& Doc Lavoisier, France, 375 pp.

Amira A., Sifi K. \& Soltani N., 2011. Measure of environmental stress biomarkers in Donax trunculus (Mollusca, Bivalvia) from the Gulf of Annaba (Algeria). European Journal of Experimental Biology, 1: $7-16$.

Belabed B.E., 2010. La pollution par les métaux lourds dans la région d'Annaba « sources de contamination des écosystèmes aquatiques». Thèse de doctorat, Université de Annaba, 199 pp.

Belabed S. \& Soltani N., 2013. Acute toxicity of cadmium on Donax trunculus: acetylcholinesterase, glutathione S-transferase activities and pattern of recovery. European Journal of Experimental Biology, 3: 54-61.

Boutabia S., 2016. Posidonia oceanica (L.) Delile, Bioindicateur de la pollution métallique du golfe d'Annaba (Nord Est Algérien). Thèse de Doctorat, Univité de Annaba, 238 pp.

Bradford M.M., 1976. A rapid and sensitive method for the quantification of microgram quantities of protein utilizing the principle of protein-dye binding. Analytical Biochemistry, 72: 248-254.

Cajaraville M.P., Bebianno M.J., Blasco J., Porte C., Sarasquete C. \& Viarengo A., 2000. The use of biomarkers to assess the impact of pollution in coastal environments of the Iberian Peninsula: a practical approach. The Science of the Total Environment, 247: 295-311.

Canesi L., Lorusso L.C., Ciacci C., Betti M., Regoli F., Poiana G., Gallo G. \& Marcomini A., 2007. Effects of blood lipid lowering pharmaceuticals (bezafibrate and gemfibrozil) on immune and digestive gland functions of the bivalve mollusc, Mytilus galloprovincialis. Chemosphere, 69: 994-1002.

Chatterjee S. \& Bhattacharya S., 1984. Detoxification of indutrial polluants by the glutathione glutathione-Stransferase system in the liver of Anabas testudineus (Bloch). Toxicology Letters, 22 :187-198.

Chouahda S., 2006. Impact de deux xénobiotiques (cadmium et halofenozide) sur Gambusia affinis et évaluation du stress environnemental dans le golfe d'Annaba par l'utilisation de Donax trunculus. Thèse de Magistère en Biologie et physiologie Animale, Université de Annaba, 76 pp.

Clark R.B., 2001. Marine Pollution. Oxford University Press, New York, 248 pp.

Cossu A., Doyotte A., Jacquin M.C. \& Vasseur P., 1997. Biomarqueurs du stress oxydant chez les animaux aquatiques. In: Lagadic L., Caquet T., Amiard J.C. \& Ramade F. (Eds.), Biomarqueurs en écotoxicologie, aspects fondamentaux. Ed. Masson, Paris, pp. 149-163. 
Cravo A., Lopes B., Serafim A., Company R., Barreira L., Gomes T. \& Bebianno M.J., 2009. A multibiomarker approach in Mytilus galloprovincialis to assess environmental quality. Journal of Environment Monitoring, 11: 1673-1686.

Deviller G., Palluel O., Aliaume C., Asanthi H., Sanchez W., Franco Nava M.A., Blancheton J.P. \& Casellas C., 2005. Impact assessment of various rearing systems on fish health using multibiomarker response and metal accumulation. Ecotoxicology and Environmental Safety, 61: 89-97.

Funes V., Asensio E., Ponce M., Infante C., Cañavate J.P. \& Manchado M., 2006. Insulin-like growth factors I and II in the sole Solea senegalensis: cDNA cloning and quantitation of gene expression in tissues and during larval development. General Comparative Endocrinology, 149: 166-172.

Habig W.H., Pabst M.J. \& Jakoby W.B., 1974. Glutathione-S-transferase: the first enzymatic step in mercapturic acid formation. Journal of Biological Chemistry, 249: 7130-7139.

ICES, 2008. Report of the Fourth ICES/OSPAR Workshop on Integrated Monitoring of Contaminants and their Effects in Coastal and Open Sea Areas (WKIMON IV). ICES, Copenhagen, 49: $71 \mathrm{pp}$.

Kaiser J., 2001. Bioindicators and biomarkers of environmental pollution and risk assessment. Science publishers Inc., Enfield, 204 pp.

Khammar H., 2008. Caractères chimiques des effluents urbains introduits au littoral d'Annaba. Mémoire de magister, Université de Annaba, 49 pp.

Lee R.F., Keeran W.S. \& Pickwell G.V., 1988. Marine invertebrate glutathione-S-transferase: purification, characterization and induction. Marine Environmental Research, 24: 97-100.

Livingstone D.R., 2010. Organic xenobiotic metabolism oxygen species production and oxidative damage in aquatic organisms. Marine Pollution Bulletin, 42: 656-666.

Mansuy D., 2013. Metabolism of xenobiotics: beneficial and adverse effects. Biologie Aujourd'hui, 207: 33-37.

Mistretta V. \& Charlier C., 2013. La surveillance biologique de l'exposition aux produits chimiques en toxicologie industrielle et de l'environnement. Annales de Biologie Clinique, 71: 257-267.

Monserrat J.M., Martínez P.E., Geracitano L.A., Amado L.L., Martins C.M.G., Pinho G.L.L., Chaves I.S., Ferreira-Cravo M., Ventura-Lima J. \& Bianchini A., 2007. Pollution biomarkers in estuarine animals: critical review and new perspectives. Comparative Biochemistry and Physiology. Part C: Toxicology \& Pharmacology, 146: 221-234.

Müller W.E.G., Koziol C., Wiens M. \& Schröder H.C., 2000. Stress response in marine sponges: genes and molecules involved and their use as biomarkers. In:
Storey K.B. \& Storey J. (Eds.), Environmental Stressors and Gene Responses. Elsevier, Amsterdam., 193-208 pp.

Nakhlé K.F., 2003. Le Mercure, le Cadmium et le Plomb dans les eaux littorales libanaises: Apport et suivi au moyen de bioindicateurs quantitatifs (Esponges, Bivalves et Gastéropodes), Thèse de Doctorat., Université de Paris, 255 pp.

OSPAR Commission., 2000. Quality Status Report 2000: Region IV - Bay of Biscay and Iberian Coast. OSPAR Commission, London, $134+$ XIII pp.

Regoli F., Frenzilli G., Bocchetti R., Annarumma F., Scarcelli V., Fattorini D. \& Nigro M., 2004. Timecourse variations of oxyradiacal metabolism, DNA integrity and lysosomal stabiliy in mussels, Mytilus galloprovincialis, during a field translocation exeprimet. Aquatic Toxicology, 68: 167-178.

Roméo M., Hoarau P., Garello G., Gnassia-Barelli M. \& Girard J.P., 2003. Mussel transplantation and biomarkers as useful tools for assessing water quality in the NW Mediterranean. Environmental pollution, 122: 369-378.

Sanders B.M., 1990. Stress proteins: potential as multitiered biomarkers. In: McCarthy J.F. \& Shugart L.R. (Eds.), Biomarkers of environmental contamination. Lewis Publishers, Boca Raton, pp. 165-191.

Soltani N., Amira A., Sifi K. \& Beldi H., 2012. Environmental monitoring of the Annaba gulf (Algeria): measurement of biomarkers in Donax trunculus and metallic pollution. Bulletin de la Societé zoologique de France, 137: 51-60.

Van der Oost R., Beyer J. \& Vermeulen N.P.E., 2003. Fish bioaccumulation and biomarkers in environmental risk assessment: a review. Environmental Toxicology and Pharmacology, 13: 57-149.

Verlecar X.N., Jena K.B. \& Chainy G.B.N., 2008. Modulation of antioxidant defences in digestive gland of Perna viridis (L.), on mercury exposures. Chemosphere, 71: 1977-1985.

Vidal M.L., 2001. Etude de marqueurs biochimiques de pollution chez le mollusque bivalve d'eau douce Corbicula fluminea (Müller) - purification et caractérisation des glutathion S-transferases. Thèse de Doctorat, Université Bordeaux 1, France, 284 pp.

Vogel S., 1977. Current-induced flow through living sponges in nature. Proceeding of the National Academy of Sciences fo the United States of America, 74: 2069-2071.

Walker C.H., Sibly R.M., Hopkin S.P. \& Peakall D.B., 2012. Principles of Ecotoxicology. Taylor and Francis, London, 353 pp.

Weckbecker W. \& Cory J.G., 1988. Ribonucleotide reductase activity and growth of glutathione-depleted mouse leukemia L1210 cells in vitro. Cancer Letters, 40: 257-264. 